\title{
KÁDÁR Beáta
}

\section{Az erdélyi magyar felsőoktatás és a munkaerőpiac kapcsolata}

\section{Bevezetés}

Az, hogy a felsőoktatásban a marketing szemléletnek teret kell nyerni a felsőoktatási expanzió, a társadalmi igények megváltozása és a technikai rohamos fejlődés révén egyértelművé vált. Szükség van a felsőoktatás piacának meghatározására, a vevők, termék konkrét lehatárolására és ki kell építeni az értékesítési csatornát.

Ami a nyugati országokban már lezajlott, az elmúlt években Romániában is jelentős piaci átalakulások történtek a felsőoktatás piacán. Új szereplő megjelenése, különböző kibővült kínálati listák alakultak ki, a bolognai folyamat révén pedig átalakult a felsőoktatás teljes struktúrája. A gazdaság területén szintén változások, átalakulások következtek be, fellendülés majd jelentős válság, szerkezeti átalakulás, ezen három kulcsfogalom egymás után jellemezte az elmúlt pár év erdélyi vállalkozói közeget.

A demokráciára jellemző romániai felsőoktatási politikát Mandel Kinga véleménye alapján semmiképp sem tekinthetjük homogénnek, sem koherensnek, állandó fejlesztési nekilendülés és visszatorpanás jellemző, ahogy a romániai politika más színterein is. (Mandel K., 2007) Nagyon gyakran változnak a miniszterek, az ő tanácsadóik, és mindenki kötelességének érzi egy új stratégia kidolgozását és azonnali hatálybaléptetését, holott a régebbieket épp csak elkezdte az előző szaktárca megvalósítani.

Romániában 2014-ben 92 akkreditált felsőoktatási intézmény volt nyilvántartva, ebből 56 állami és 37 magánegyetem, mindez 21,33 millió lakosra (2011-es népszámlálási adatok eredményeképp). Mivel a kutatásomban a romániai magyarok helyzetén vizsgálom, fontos tudnunk, hogy a népszámlálási adatok értelmében Románia lakosságának kb. 6\%-át teszik ki a magyarok, ami kb. 1,2 millió főt jelent.

Jelen tanulmány keretei között a következő hipotézisek vizsgálatára vállalkozom:

1. A Sapientia Erdélyi Magyar Tudományegyetem és a Babes Bolyai Tudományegyetem - a két nagy erdélyi felsőoktatási piaci szereplő - megítélése a végzettek körében szignifikáns különbséget mutat az oktatás minőségével való elégedettséget illetően.

2. A hallgatók egyetemválasztási motivációit tekintve döntő tényező, hogy milyen nyelven folyik az oktatás az adott felsőoktatási intézményben, és hogy mekkora távolság van a lakhelyük valamint a felsőoktatási intézmény között.

\section{Anyag és módszer}

Módszertanilag kutatásomban kvalitatív és kvantitatív módszereket egyaránt alkalmaztam. A jelenlegi egyetemisták körében végeztem fókuszcsoportos vizsgálatot. A két nagy erdélyi magyarul is tanító egyetem hallgatói között zajlott 8 vizsgálat, átlagosan 70 percet tartott egy alkalom. Lebonyolítását saját szervezésben a Sapientia EMTE Csíkszeredai Karának kutató laborjában végeztem, 2017 májusjúniusában. Vállalatvezetőket kértem fel félig strukturált interjúkra. ISCED szakterületenként 2-2 erdélyi vállalatvezetőt választottam. Nem konkrét kérdéseket tettem fel számukra, hanem csak témaköröket jelöltem meg, amiről aztán elbeszélgettünk, esetleg segédkérdésekkel pontosítottam a témát. Kvantitatív kutatásként a kérdőíves vizsgálati módszert választottam. Az online kérdőívet leginkább a 
legelterjedtebb közösségi média segítségével népszerüsítettem. A felhívásban az szerepelt, hogy megkérek minden olyan 2005 és 2015 között egyetemet végzett erdélyi magyart, aki szívesen hozzájárulna az egyetemek és a munkaerőpiac tevékenységének összehangolásához, hogy töltse ki a kérdőivet, ezzel is segítve, hogy képet kapjunk arról, mennyire tudják az egyetemi é2évek alatt tanultakat hasznosítani a munkaerőpiacon. A kérdőívet minden magyar egyetemi diákszervezethez, ifjúsági szervezethez, alumni gyújtőlistára eljuttattam, nagyon sokan komolyan vették a kutatási kérdést, és továbbították ismerőseiknek, megosztották a közösségi médiában. Így kevesebb, mint 2 hónap alatt összegyúlt 379 válasz, amiből 4-et kellett teljesen kivágni, ugyanis nagyon sok kérdésre hiányzott a válasz. A fennmaradó 375 kérdőív értékelhető, hasznos információkat tartalmaz.

A kolozsvári egyetemi oktatás régi időkre nyúlik vissza, jelen keretek közt röviden áttekintjük az 1945-től való történéseket, ekkor jött létre a magyar tannyelvú állami egyetem, ami még abban az évben kapta a Bolyai Tudományegyetem nevet, Bolyai Farkas és János matematikusok szakmaisága előtt tisztelegve. 1948 májusában veszi fel az I. Ferdinánd Tudományegyetem a világhírú kutatóorvos, Victor Babes nevét. 1959-ben valósult meg az egyetlen kolozsvári állami egyetem létrehozása a két intézmény összevonásával, Babes- Bolyai Tudományegyetem néven. Egy nagy áttörés 1995-ben történt egy reform formájában, amikor multikulturális alapokra helyezték az oktatást, román, magyar és német tagozatok létrehozásával, az egyetemnek összesen 21 kara van, 17 karon folyik magyar nyelvű oktatás is és 9 karon német. összesen 119 magyar tannyelvű alap és mesterszak múködik.

A Sapientia Erdélyi Magyar Tudományegyetem 2001-ben alakult, két helyszínen kezdve az oktatást, Csíkszeredában és Marosvásárhelyen, 2002-től már Kolozsváron is elindult a képzés. Mostanra négy helyszínen zajlik az oktatás, 31 alapképzési szakra és 12 mesteri szakra várják a hallgatókat. Az intézményt Magyarország kormánya a történelmi egyházakkal karöltve hozta létre, azon régi törekvés testesült így meg, hogy legyen önálló magyar nyelvű képzés Erdélyben.

Az egyetem küldetési nyilatkozatában olvashatjuk, hogy törekszik a versenyképes minőségi oktatás és kutatás biztosítására, a regionális igényeket kielégítő korszerű szervezetté szeretne válni és széleskörű kapcsolatok kiépítésére törekszik, amelyeket nyitottság, megbízhatóság, odaadás és kölcsönösség jellemez.

Az egyetem Romániában magánegyetemként van besorolva, amely minden romániai felsőoktatási törvénynek, szabályozásnak megfelel és így akkreditált intézmény. Romániai állami támogatásban egyáltalán nem részesül.

A fókuszcsoportos beszélgetésekben érintett főbb kérdéskörök:

- középiskolásként milyen szempontok alapján döntött, hogy milyen szakon/ milyen egyetemen tanuljon tovább?

- egyetemistaként mi a véleménye az egyetemi oktatásról?

- az egyetemi oktatásban milyen hiányosságok lát?

- mit gondol, az egyetemen szerzett tudással el tud helyezkedni a munkaerőpiacon?

- meglátása szerint milyen elvárásokkal áll majd szemben a munkáltatónál?

- milyen javaslatai vannak az egyetemi képzést illetően? milyen tényezők növelnék az elégedettségét?

Mindkét egyetemen bizonytalannak, elesettnek tüntek az elsőévesek, beszéltek azokról a tárgyakról, amiket tanulnak, de csak csoportonként egy -két diák tudta összekapcsolni a szakmájával és magyarázta 
el, hogy mire is fogja tudni használni majd az egyes tantárgyakból tanultakat. Sőt ez a közel egy tanév sem volt elegendő arra, hogy a csoportonként felénél több hallgatónak legyen elképzelése arról, hogy hol tud elhelyezkedni a szakmával, amit közel egy éve tanul.

Bár a fentiek jellemzőek általában a csoportokra, mégis megállapítható volt, hogy az 1-es (oktatás), 4-es (természettudományok, matematika és számítástechnika), 5-ös (egészségügy és népjólét), 6-os (műszaki tudományok, gépgyártás és építőipar) csoportba tartozók kicsit tudatosabbak, de csak mert a szakmájuk sokkal inkább körülhatárolható: „tanár leszek”, „építészmérnök leszek”, „informatikusnak készülök” de erről sem tudtak a saját célokkal átitatottan nyilatkozni. PI. ha rákérdeztem, hogy konkrétan melyik iskolák közül szeretne valamelyikben tanítani, akkor arra már nem jött válasz, vagy hogy saját építkezési vállalatot szeretne-e, esetleg milyen típusú épületeket szeretne tervezni, ezekre a kérdésekre már mind hiányoztak a válaszok.

Összegzésként elmondható, hogy az alanyok jelentős része azt a jövőüket meghatározó fontos döntést, hogy mit tanuljanak, és így milyen esélyeket szerezzenek a munkahelykeresésben az érettségi és az egyetemre való jelentkezés között rendelkezésére álló egy hétben hozta meg. Kíváncsi voltam, hogy vane olyan a csoportban, aki azt érzi, rosszul döntött, és nem tetszik az, amit tanul, megközelítőleg 1/3-ad arányban mondták, hogy sokszor érzik így, de ha már belekezdtek, megpróbálják befejezni.

A munkáltatók részéről aziránt érdeklődtem, hogy mi a véleményük a felsőoktatásból frissen kikerülők szakmai ismereteiről, hozzáértéséről, amit a félig strukturált interjúk segítségével mértem fel. Rákérdeztem az esetleges hiányosságokra, azok okaira is. Továbbá a véleményüket is megkérdeztem, az egyetemi oktatást illetően, milyen pozitívumokat tudnak felsorolni, milyen negatívumokat látnak és hogy vannak-e javaslataik az egyetemek felé. Az alanyaimat minden esetben arra kértem, hogy amennyiben a szakmai fórumokról, partnereikkel való találkozókról további véleményeket is fel tudnak hozni a témában, osszák meg azt is velem, hogy minél részletesebb képet kapjak az alkalmazói szféra véleményéről.

Jelen tanulmányban az ISCED osztályozás szerint a humántudományok és múvészetek, a természettudományok, matematika és számítástechnika valamint az egészségügy és népjólét szakterületek alapján készített interjúkat mutatom be.

A humántudományok és múvészetek szakcsoport részéről egy színházigazgatót és egy könyvtárigazgatót kerestem fel. A színházigazgató szerint a legnagyobb gond, hogy ha valaki egyáltalán nem tehetséges, de elhatározza, hogy színész akar lenni és nagyon kitartó, színész is lesz, legalábbis oklevele lesz róla, és akkortól már valamilyen formában foglalkoztatni kell, pedig ne feledjük, nem tehetséges. Tovább fokozza a problémát, hogy ha ennek a valakinek még befolyásos ismerőse is van, mert a romániai magyar múvészi világ ilyen... ha ismerősöd van, nyílnak meg a kapuk előtted, ha nem is vagy tehetséges. Szerinte a képzés nagyon jó minőségü, felveszi a versenyt a nyugati múvészképzőkkel is, csak hát oklevelet csak azoknak kellene adni, akik kiválóak. Vagy meg lehetne különböztetni A és B típusú múvészeket. B típusú a kitartó, de kevésbé tehetséges, az is lehet, hogy vannak pozíciók, ahová ilyen emberekre van szükség. Az igazgató szerint több idegen nyelvet és menedzsment készséget kellene elsajátítani a múvészeknek. A magyar nem világnyelv, ő már csak úgy engedne múvésziskolákat múködni, ha legalább még egy nyelven folyékonyan beszélnének a végzősök. Emellett pedig fontos lenne, hogy tudják menedzselni saját magukat, saját csapatukat, társulatokat, nem beszélve a személyes időbeosztásról, stb.

A könyvtárigazgató arról számolt be, hogy mennyire megváltozott ez a szakterület is, hogy most már nem elég olvasottnak lenni, jártasnak kell lenni az informatika terén, a különböző szervezési feladatokat 
is el kell tudni látni, és emellett kommunikációs, népszerúsítő, PR ismeretekre is szükség van. Mert most már fontos, hogy a könyvtár élő legyen, rendezvényeket szervezzenek ott az olvasóknak és a potenciális olvasóknak. Az olvasást, a könyvtárat, a könyvtárba járást mind-mind reklámozni, népszerúsíteni kell, és ritkán van lehetőség arra, hogy szakembert alkalmazzunk erre a pozícióra. Az adatbázisok használata, a gyors kikeresés/ kiszolgálás felértékelődött, fontos, hogy az olvasó ne kelljen várnia, keresgélnie, ma már annak kell örülni, hogy van idő olvasni és belépni az olvasnivalóért a könyvtárba, az ott adminisztrálással töltött időt minimalizálni kell. Összegzésképp elmondta, hogy most már nem elég elvégezni egy humán szakot (nyelvet, irodalmat), ahhoz hogy a könyvtárban el tudja látni az illető a feladatokat. Szerinte szükség van vezetési, szervezési ismeretekre valamit PR tudásra, és azt is javasolná az egyetemeknek, hogy ezeket a tárgyakat vezessék be a humán képzésbe is, mert másképp nem lesznek versenyképesek a frissen végzettek. Mint problémát említette az igazgató a fiatalok felpörgött életritmusát, hogy szerinte nehezen tudnak hosszabb feladatokra koncentrálni, s azt alaposan elvégezni, munkaidejüket a multitasking határozza meg és ez a teljesítményükre ebben a szakmában nem mindig van jó hatással.

Egy kutató labor igazgatóját és egy programozó cég vezetőjét kértem fel egy-egy beszélgetésre a természettudományok, matematika és számítástechnika ISCED területről. A kutató labor vezetője nagyon meg volt elégedve a frissen végzett alkalmazottakkal, évente gyakornokokat is fogad, és ha új alkalmazottat keres, akkor is jellemzően frissdiplomást alkalmaz. Hosszasan beszélt arról, hogy a természettudományokat el lehet sajátítani az egyetemen, ha az ember alaposan megtanulja a leadott tananyagot, és mostmár egyre több lehetőség van gyakorlatozásra is, annak, aki valóban érdeklődik a szakma iránt, kísérleteket is lehet már végezni az egyetemeken. Mégis az az igazán eredményes, ha a diák különböző kutató laborokban gyakorlatozik, ott többet tanul. A szakma gyakorlati elsajátításában látott fejlődési lehetőséget az igazgató, azt mondja, ahhoz az egyetemeknek több pénzt kellene a gyakorlati órák eszközeire, fogyóanyagaira fordítani, hogy még jobban meg tudják tanítani a hallgatóknak az anyagot, amit gyakorlatba is ültethetnének ezáltal azonnal, laboratóriumi körülmények között. De többször is hangsúlyozta, ha elhivatott természettudósról beszélünk, aki mindent megtanult az egyetemen, a gyakorlat terén nagyon gyorsan fel tud majd zárkózni.

A programozó cég vezetője szerint a programozás külön terület, szerinte erre jól nem nagyon készítenek fel Romániában, mivel nagyon gyorsan fejlődő területről beszélünk, csak akkor lehetne ezt jól tanítani, ha a tanárok is állandóan újratanulnák a tananyagot, de mivel ez nem így van, régebbi programozási nyelveket tanítanak, mondván, hogy ez volt minden programozás alapja, csak a mai vállalkozót nem érdekli, hogy tudsz-e ősnyelven. Azzal a példával élt, hogy aki román nyelvet kell tanítson, nem tanítja meg a latint is, és nem tanítja meg a régi helyesírási szabályok szerint is a nyelvet. Így kellene ezt a programozásban is. Még egy fontos egyedi tényezőre hívta fel a figyelmet a cégvezető, mégpedig arra, hogy ha a programozói szakmát már az egyetemen komolyan veszi valaki és autodidakta módon hozzá tanul az ott elhangzottakhoz, szinte biztos, hogy túlszárnyalja a mesterét, így versenyelőnyben lévő konkurencia válik belőle, ezért is van a tanárokban az a kettősség, ahogy ezt a szakmát tanítják. Ettől függetlenül ő szívesen dolgozik frissen végzettekkel, mert szerinte minél fiatalabb valaki, annál lelkesebb, annál fogékonyabb és annál gyorsabban tanul. Meglátása szerint az egyetemi oktatás nem fog változni belátható időn belül, így javaslata sincs az egyetemek felé. A diákok felé van: nyitottan, érdeklődően mindent meg lehet tanulni, akár saját maguktól is, erre törekedjenek.

Az ISCED listán tovább haladva (egészségügy és népjólét), megkerestem egy egészségcentrumnak a vezetőjét és egy kórházigazgatót. Az egészségcentrumban több gyógytornász és logopédus is dolgozik, főként rájuk vonatkoztatott a vezető, amikor kifejtette a véleményét. Azt elmondta, hogy szerinte nem kifizetődő frissen végzettet alkalmazni, mert sok tanulni való marad az egyetem utánra, bár az alapokat 
nagyon jól lefektetik és bizony megtanítják mindenkinek a szükséges minimumot, abból még jó szakemberré nem lehet válni. Ezeket az orvostudományt kiegészítő szakmákat mostohaként kezelik, holott sok esetben megelőzésben, rehabilitálásban csak ezáltal tud teljes lenni az orvosi ellátás. Ahhoz hogy valaki eredményes legyen ebben a szakmában és magabiztosan merjen vállalni bonyolultabb kérdéseket is, nem csak a népbetegségeket, tovább kell magát fejlesztenie, fizetéses kurzusok révén, orvosok melletti asszisztálás segítségével. Nagyon bevett szokás, hogy pl. a gyógytornászok egy-egy ortopédiai magánklinikán „tanulnak” tovább, még akár úgy is, ha saját forrásból fizetniük kell a gyakorlatért. Szerinte gyökeres változtatásra lenne szükség, és tanévenként 1-1 félév gyakorlatra, hogy a hallgatók jól begyakorolják minden területét a szakmának, ami persze azzal is járna, hogy legalább egy évvel hosszabb kellene legyen az képzés. Itt is az volt a vélemény, hogy jól megtanítják a diákoknak az elméleti anyagot, inkább a gyakorlat fejlesztésére kellene nagyobb hangsúlyt fektetni.

A kórházigazgató nem tûnt nyitottnak, sok egyeztetés után tudtunk csak találkozni és akkor is szinte teljesen elzárkózó volt. Kicsit azt a látszatott keltette, mintha nem is értené a kutatásomban felmerült kérdéseket. Minden tökéletesen múködik az egészségügyi képzésben, ez volt a fő üzenete. Két mondatát tudom kiemelni, ami alapvetően hiányosságot, nehézséget is tárt fel, egyik szerint problémás az egészségügyi alkalmazottak bérezése és küzdenek a jól képzett szakemberek elvándorlásával a másik problémáról így fogalmazott: „aki ötösre vizsgázik minden tárgyból, az is orvos lesz, s aki tízessel, az is”. Viszont nem sikerült rávennem arra, hogy ezt a véleményt kifejtse. Amikor a kórház alkalmazottairól, friss diplomásairól kérdeztem, maximális elégedettséget tanúsított, minden orvossal, asszisztenssel és azok szakmai felkészültségével maximálisam meg van elégedve.

Kvantitatív kutatásomhoz azért választottam a 2005 és 2015 között oklevelet szerzőket kutatásomhoz, mert 2005-ben végzett az első évfolyam a Sapientia Erdélyi Magyar Tudományegyetemen. Ez az intézmény jelentősen megváltoztatta az addigi szerkezetet, oktatási kínálatának és karainak térségbeli elhelyezkedésének köszönhetően olyan erdélyi fiatalok is továbbtanulhattak, akiknek addig anyagi vagy kulturális, nyelvi akadályaik voltak, jelentősen kevesebb pénzből tanulhattak az anyanyelvükön, közel a lakhelyükhöz. És azért zártam a 2015-ben végzett generációval, mert úgy gondolom, kutatásom sikeréhez az tud igazán hozzájárulni, akinek van 1-2 év tapasztalata a munkaerőpiacon.

A kvantitatív adatfelvétel során gyújtött mintában jelentősen felülreprezentáltak a nők. Ezt több tényezővel is magyarázhatjuk, legfontosabb, hogy a 2011-es romániai népszámlálási adatok eredményeképp kiderült, hogy a romániai magyarok 52\%-a nő, továbbá a felsőfokú végzettek körében több a nő, a romániai magyar nők 10,6\%-a rendelkezett felsőfokú oklevéllel, míg a férfiak 9,8\%-a. (Veres V. - Attila P. Z., 2012, Népszámlálás 2011.) Természetesen azt a szempontot sem szabad elvetni, hogy a nők általában segítőkészebbek, könnyebben, szívesebben osztják meg a véleményüket, így valószínű ebből is fakad, hogy több nő töltötte ki a kérdőívet. A 26 és 35 év közöttiek jelentik a minta jelentős részét, viszont Öröm azt látni, hogy 63 olyan 25 év alatti személy is kitöltötte a kérdőívet, akinek sikerült a szakmában elhelyezkedni, kitéve így a válaszadók közel 17 százalékát. A válaszadóim $76 \%$-ának volt az állandó lakhelye városon a diploma megszerzésének pillanatában és 77,1\%-uk lakik most városon, szóval jelentős eltérésről nem számolhatok be.

Bár a kérdőív bevezetőjében arra kértem a válaszadókat, hogy a 2005-2015 között végzettek töltsék ki, a 14 db. 2016-ban végzett válaszát is benne hagytam az elemzendő mintában, ugyanis azt gondolom, hogy örömteli, ha már az egy évvel ezelőtt végzettek is el tudtak helyezkedni a szakmában és az összehasonlító vizsgálatoknál érdekes tények derülhetnek ki. 
A válaszadóim 76\%-ának volt az állandó lakhelye városon a diploma megszerzésének pillanatában és 77,1\%-uk lakik most városon, szóval jelentős eltérésről nem számolhatok be.

1. ábra: Mennyire fontosak az egyetemválasztás során az egyes tényezők?

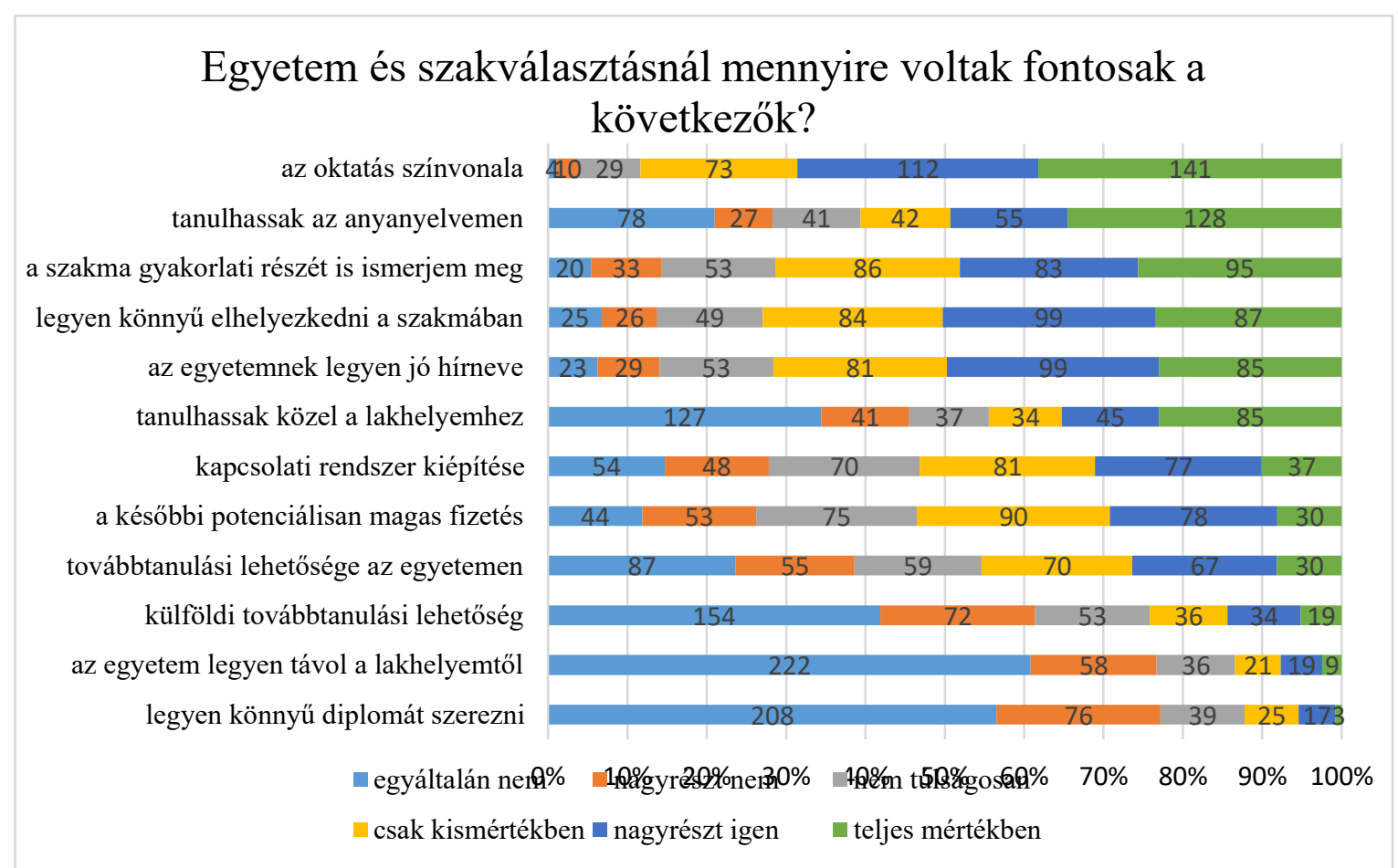

\section{Forrás: saját szerkesztés}

A fenti ábrán látjuk, hogy milyen mértékben tartották fontosnak az alanyok az egyetem és a szakma választásánál fontosnak a felsorolt tényezőket, az oktatás színvonala tűnik az egyetemválasztásnál a legfontosabb tényezőnek továbbá az anyanyelven tanulás, a szakmában való könnyű elhelyezkedés reménye valamint a szakma gyakorlati részének elsajátíthatósága szintén fontos tényezők. Az alanyok döntését legkevésbé a könnyű diplomaszerzés, a külföldi továbbtanulási lehetőség és a lakhelytől való távolság befolyásolja.

2. ábra: A válaszadók nyelvismerete

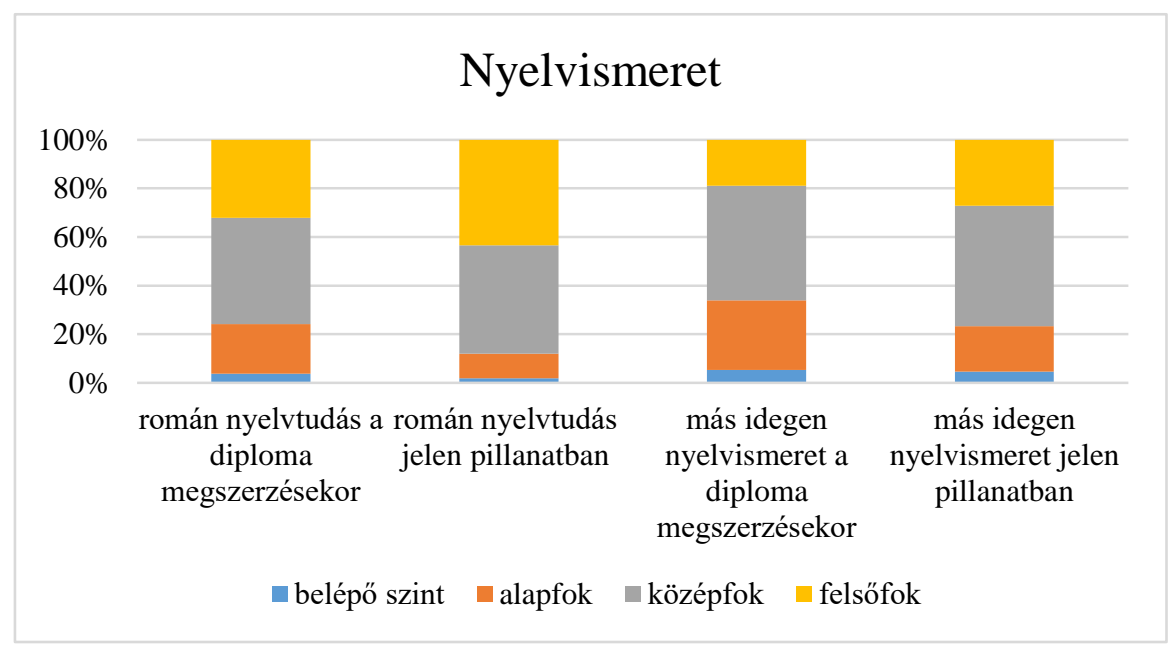

Forrás: saját szerkesztés 
A fenti ábrán láthatjuk, hogy sokan csak a munkavállalás után eszméltek rá a román nyelvtudás fontosságára és azután hozták be nyelvismereti hiányosságaikat. Bár magyar tannyelvú iskolákba járnak a diákok, románt már az óvodától tanulnak, igaz, nem mint idegen nyelvet, és a tömb-magyar közösségekben a környezetükben olykor nem is hallanak román szót, így gyakorlatilag úgy érettségiznek a magyar diákok, hogy tudnak románul verset elemezni, mondatot elemezni nyelvtanilag, de nem tudnának egy hétköznapi beszélgetést lefolytatni. És ezen nem mindig segít, ha román nyelvű felsőfokú képzést választanak, ugyanis ha román egyetemre nyernek felvételt, ott megtanulják a szakkifejezéseket, de a társalgási képesség továbbra is alulmaradhat. Jelentős probléma, hogy egy alapellenállás is van a románok és a román nyelv iránt, így gyakorlatilag elutasítanak minden olyan lehetőséget, amely a nyelv megtanulásához járulna hozzá. Mindez jelentős elhelyezkedési problémákat okoz a munkaerőpiacon, legtöbb szakmában még a tömb-magyar közösségekben is kell tudni középfokon románul, ami a legtöbb magyar ajkú fiatalnál problémát okoz. Amint az ábrán is látjuk, más idegen nyelvekkel jártasabbak már az egyetemi évek alatt az alanyok.

Továbbá azt is megvizsgáltam az ANOVA módszerével, hogy van-e szignifikáns különbség aközött, hogy ki melyik egyetemen tanult, tekintettel arra, hogy hányadik munkahelye kapcsolódik a szakterülethez, de az elemzés szintén arra mutatott rá, hogy ebben az esetben sem lelhető fel az egyetemek között szignifikáns különbség.

Nem találtam szignifikáns kapcsolatot aközött sem, hogy ki hol tanult illetve mire vezeti vissza szakmai hiányosságait. Mégis úgy gondoltam, fontos lenne megvizsgálnom legalább a két nagy erdélyi magyar/magyarul is oktató felsőoktatási intézmény esetében, amint a lenti ábrán láthatjuk, a Sapientiások inkább saját hibájuknak tudják be a hiányosságaikat és a Babes végzettei többen tulajdonítják a hiányosságaikat az egyetemi rendszernek és az egyetemi oktatóiknak, mint a Sapientiások. Szakmai tudásukkal elégedettebbek a Sapientiások, ők 7,3\%-ban mondták, hogy nincsenek szakmai hiányosságaik, míg a Babesesek 5,6\%-a.

3. ábra: A válaszadók szakmai hiányosságaikat minek tudják be?

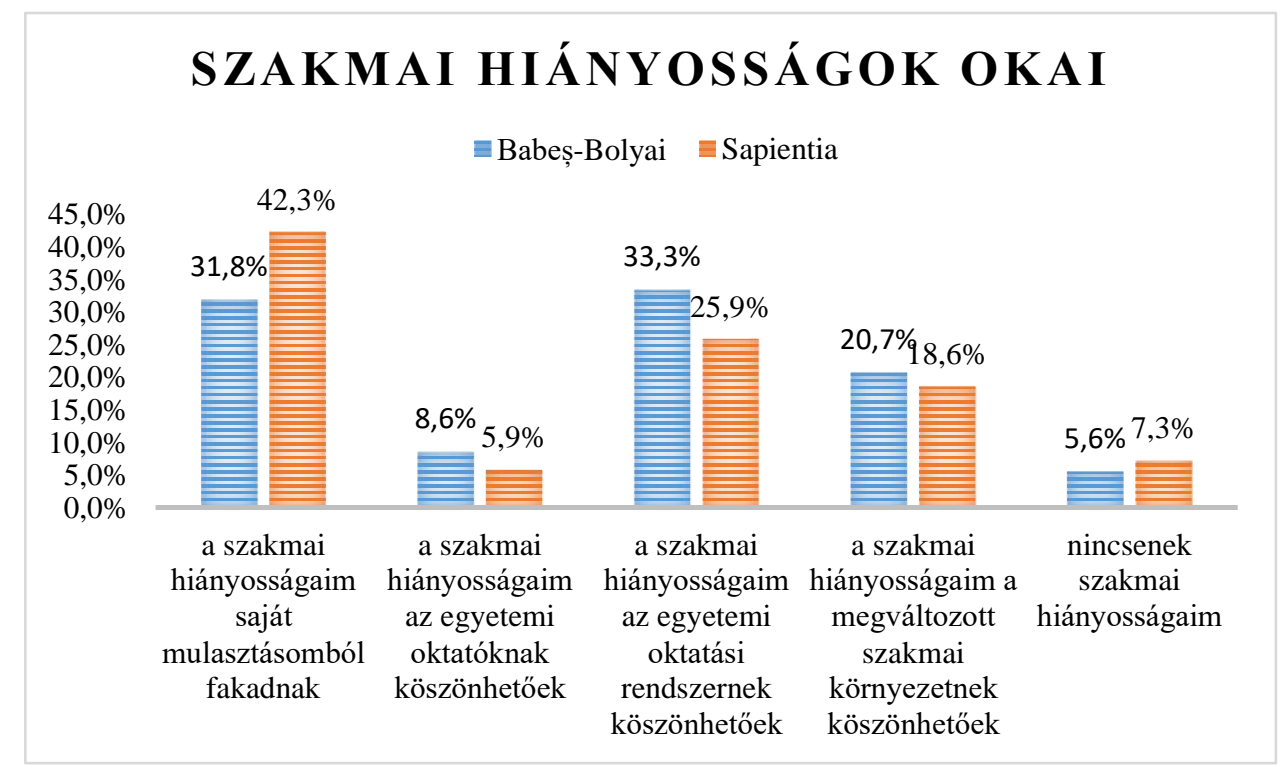

Forrás: saját szerkesztés

A kérdőívem utolsó kérdésében arra kértem alanyaimat, hogy ha volt külföldi munkatapasztalatuk az egyetemi évek alatt, három szóval jellemezzék azt, a lenti szófelhő mutatja, hogy melyek azok a szavak, 
amelyek leggyakrabban fellelhetőek a válaszokban. A külföldi munka az idegennyelv, a kaland és a tapasztalatszerzés kifejezésekkel írható le leginkább a válaszadóim szerint, de a kaland, a szórakozás, az önállóság, a tanulás, kapcsolatok mind kiemelt szerepet kaptak a válaszokban. Azt gondolom, azért is érdemes volt a szófelhőt elkészíteni, hogy lássuk, általában utólag pozitívan értékelik a külföldi munkát azok, akik bevállalják ezt a kihívást. Megfigyelhetjük, hogy a külföldi munkatapasztalat során sokan önállósodtak, sokan éreztek megbecsültséget, elismerést, sőt a külföldi munkavégzést következetesnek ítélték.

4. ábra: Szófelhő a válaszok alapján

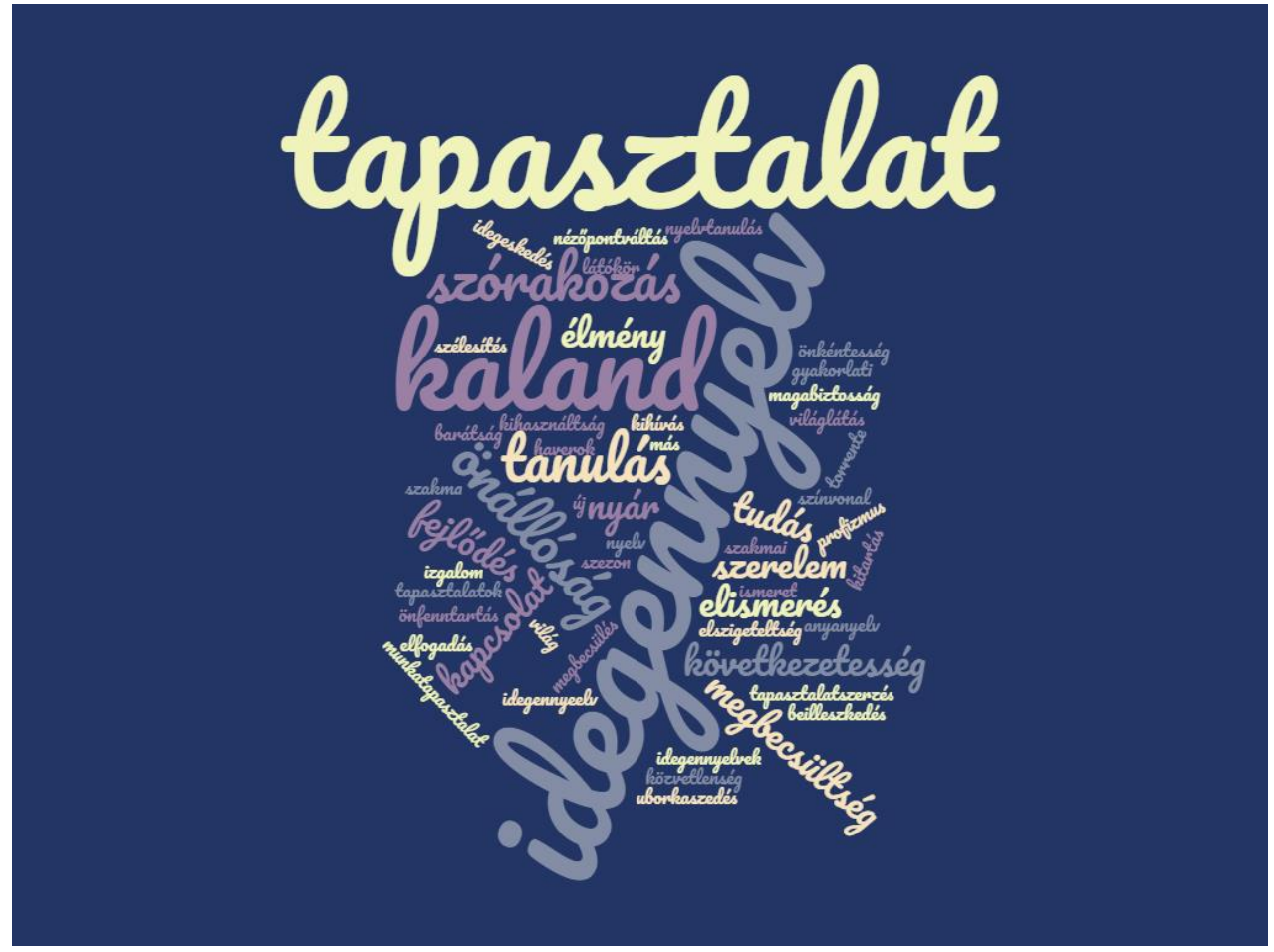

Forrás: saját szerkesztés

\section{Következtetések}

Alább a hipotézisek kapcsán felállított következtetések:

A Sapientia Erdélyi Magyar Tudományegyetem és a Babes Bolyai Tudományegyetem - a két nagy erdélyi felsőoktatási piaci szereplő - megítélése a végzettek körében szignifikáns különbséget mutat az oktatás minöségével való elégedettséget illetöen.

A hipotézist nem sikerült alátámasztani, ugyanis sem a kérdőíves adatfelvétel sem a fókuszcsoportos vizsgálat során nem születtek olyan válaszok, amelyek alapján arra következtethetnék, hogy két nagy felsőoktatási intézmény megítélése között szignifikáns különbség van. A középiskolai véleményformálók, a tanárok és iskolaigazgatók a Sapientia EMTE indulásának időszakában az új szereplőt kétséggel fogadták a piacon, de ahogy az a versenyszférában lenni szokott, itt is erős ellenállást tanúsítottak a versenytársak is, kétkedés és ódzkodás jellemezte a gazdasági szereplőket is új intézmény végzettei irányában. Ám jelen kutatási is bizonyítja, az intézménynek mostanra bizonyítottan is létjogosultsága van, azok, akiknek már sikerült is kipróbálni a felsőoktatási intézményektől kapottakat a munkaerőpiacon nem látnak eltérést a nyújtott szakmai háttér között.

A hallgatók egyetemválasztási motivációit tekintve döntő tényezö, hogy milyen nyelven folyik az oktatás az adott felsőoktatási intézményben, és hogy mekkora távolság van a lakhelyük valamint a felsőoktatási intézmény között. 
Jelen hipotézist is részben tudom elfogadni, ám mindenképp fontos tényezőként szerepel az anyanyelv egyes hallgatói csoportok körében, ezen tényező mentén szilárdan elkülönülnek egymástól az egyes klaszterek, van akinek elsődleges szempontként szerepel az anyanyelven való továbbtanulás az egyetemválasztásnál. A szakma anyanyelven való elsajátítását fontosnak tartja az erdélyi magyarok jelentős része. Az is látszik a kutatásból, hogy a román környezetben való tanulás nem jelenti azt, hogy a román nyelvet jobban elsajátítja az ember. A lakhelytől való távolság már kevésbé, de még mindig igen jelentős hatást gyakorol a döntésre, két klaszterben is marginális pont, egyikben éppen az, hogy közel legyen a lakhelyhez az egyetem, egy másik klaszterben meg épp az ellenkezője a döntő, hogy távol legyen a lakhelytől az egyetem, ahol továbbtanulnak, amint az a lenti ábrán is látható.

5. ábra: A klaszterek egyetemválasztási szempontjai

\section{Az egyes klaszterek egyetemválasztási preferenciái}

—csak lazán $\rightarrow$ itthon maradok

$\rightarrow$ anyanyelven is lehet karriert

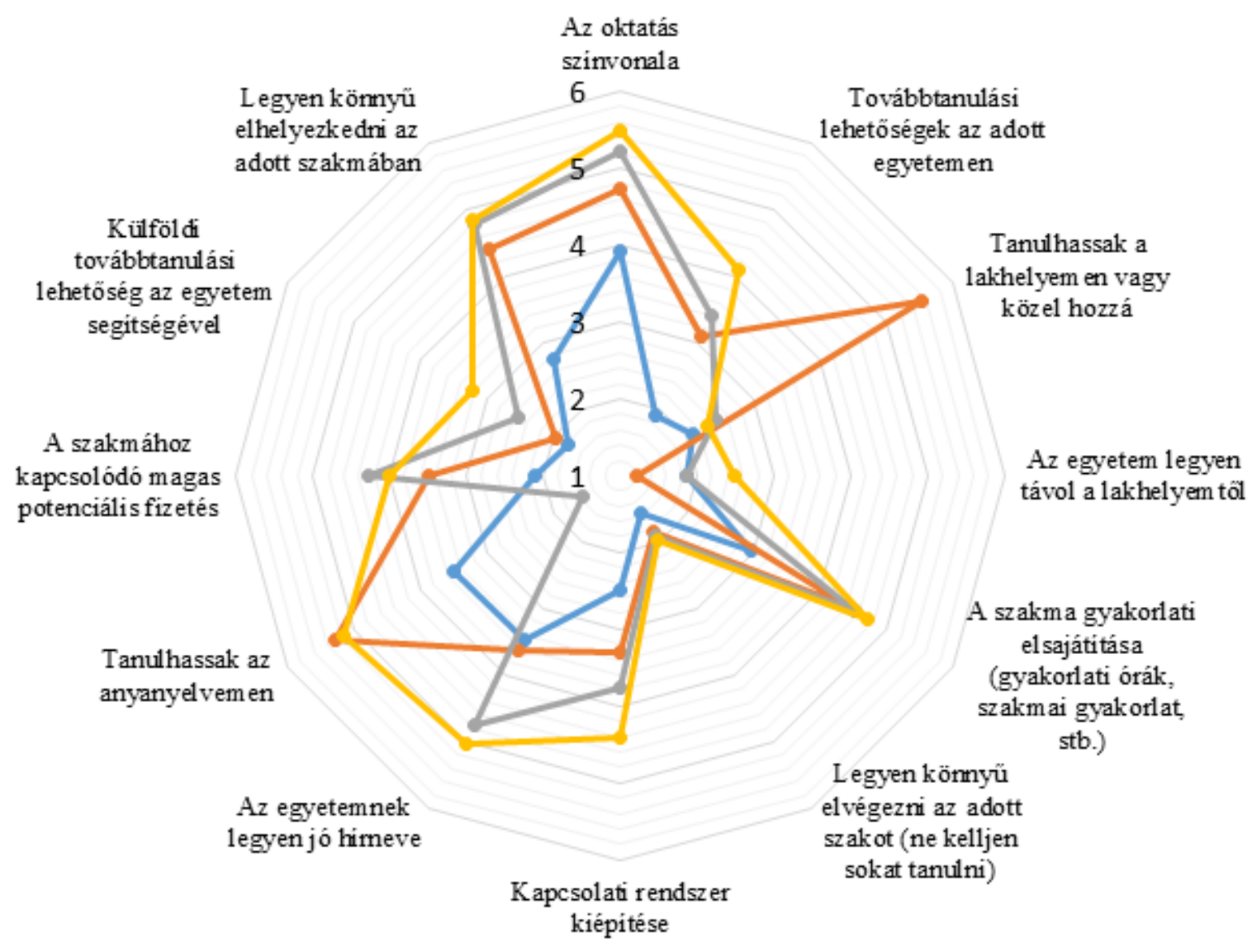

Forrás: saját szerkesztés 


\section{Felhasznált szakirodalom}

- Andreé, S. (2014) Programul de Evaluare Instituțională 2012-2014, Európean Committee, Bukarest

- Duga Zs. (2010): Az egyetemek szerepe a regionális fejlesztésben. PTE-KTK, Félidőben Konferencia, 2010. október 8-9., Pécs In: Buday-Sántha A. - Gunszt K. - Horváth M. - Milovecz Á.- Páger B. - Tóth Zs. - Balogh G. - Kovács Sz. - Horeczki R. - Erdősi F. - Horváth Gy. (szerk.) Évkönyv 2010:"Félidőben" Pécs: PTE KTK Regionális Politika és Gazdaságtan Doktori Iskola, pp. 36-47.

- Duga Zs., (2016): Az alumni szolgáltatások szerepe a hazai egyetemek múködésében (PhD értekezés), Pécsi Tudományegyetem, Pécs

- Elena, F. - Alexandru, M. - Bogdan, F. (2015): The challenges of Romanian HIgher Education - A review on a key enablers for modernization. Procedia Technology, Vol. 22. (2016) p 1121-1128

- European Committee (2013) Lifelong Learning Policy Retrieved from: http://ec.europa.eu/education/index_en.htm (07 01 2013)

- Florax, R. (1992): The university: A Regional Booster? Economic Impacts of Academic. Knowledge Infrastructure. Avebury, Aldershot.

- Gál Z. - Zsibók Zs. (2013): Az egyetemek szerepvállalása a regionális innovációsrendszerben és az innovációs kormányzásban. In: Gál Z. (szerk) (2013): Innovációbarát kormányzás Magyarországon. A regionális innovációs fejlesztéspolitika kihívásai. MTA Közgazdaság- és Regionális Tudományi Kutatóközpont Regionális Kutatások Intézete, Pécs

- Institutul Național de Statistică (2011). Recensământul populației. Retrieved from http://www.recensamantromania.ro/rezultate-2/ (26 01 2018)

- International Standard Classification of Education: ISCED Retrieved from: http://ec.europa.eu/eurostat/statisticsexplained/index.php/International_Standard_Classification_of_Education_(ISCED) (26 01 2018)

- Kinga, M. (2007). A román felsőoktatás-politika változásai 1990-2003 között: egyetemi jegyzet. Cluj-Napoca: Presa Universitară Clujeană.

- Náray - Szabó G. (2011): Kutatás és versenyképesség a felsőoktatásban. In: Berács J. - Hrubos I. - Temesi J. (szerk.): „Magyar Felsőoktatás 2010” Konferencia dokumentumok, NFKK Füzetek, 2011 Budapesti Corvinus Egyetem.

- OECD (2012a) (szerk.): Tremblay, K., Lalancette, D. és Roseveare, D., Assessment of Higher Education Learning Outcomes, Feasibility Study Report, Volume 1 - Design and Implementation, Retrieved from: http://www.oecd.org/education/skills-beyondschool/AHELOFSReportVolume1.pdf (15 12 2012)

- Valér, V., \& Attila, P. Z. (2012). Szociológiai mintázatok: erdélyi magyarok a Kárpát Panel vizsgálatai alapján. Kolozsvár: Nemzeti Kisebbségkutató Intézet (Editura Institutului pentru Studierea Problemelor Minorităţilor Naţionale). 